\title{
DESAIN PENGEMBANGAN MODUL GEOMETRI LUKIS
}

\author{
Siti Nuriyatin ${ }^{1}$, Soffil Widadah ${ }^{2}$ \\ ${ }^{1,2}$ STKIP PGRI Sidoarjo \\ sitinuriyatin@gmail.com ${ }^{1}$, sofdah16@gmail.com²
}

\begin{abstract}
ABSTRAK
Penelitian ini bertujuan untuk mendeskripsikan desain pengembangan modul Geometri Lukis. Research and Development merupakan metode dalam penelitan ini. Modul yang dikembangkan ini disajikan untuk mendukung kemampuan pengajuan soal Geometri Lukis. Subyek penelitian adalah mahasiswa pendidikan Matematika STKIP PGRI Sidoarjo. Instrumen yang digunakan adalah lembar validasi, lembar tes dan lembar angket. Hasil validasi ahli memperoleh skor 4,64 dengan kategori sangat valid. Hasil angket sebesar 80,55 dengan respon positif. Hasil tes menunjukkan sebesar $80 \%$ subyek mampu mengajuakan soal dengan benar. Hasil validasi dan uji coba menunjukkan bahwa modul Geometri Lukis yang dikembangkan mempunyai kelayakan untuk digunakan.
\end{abstract}

Kata kunci: geometri lukis, modul, pengajuan soal.

\begin{abstract}
This study aims to describe the development design of Geometri Lukis module. This study is Research and Development. This module was developed to support problem posing ability of Geometri Lukis. The subject by involving prospective teacher of Mathematic Education, STKIP PGRI Sidoarjo. Instrument used is the validation sheet, test, and questionnaire. Validation result is 4,64 with a valid category. Students responses were positive by score 80,55 . The test result is $80 \%$ of subjet be able to propose question and right answer. The result showed that the Geometri Lukis module feasible to used.
\end{abstract}

Keywords: geometri lukis, module, problem posing.

\section{PENDAHULUAN}

Kompetensi pedagogik, kepribadian, sosial, dan professional merupakan kompetensi wajib yang harus dimiliki seorang guru. Kompetensi tersebut mulai diasah ketika seseorang akan menjadi calon guru, tidak terkecuali calon guru matematika. Kondisi ini menuntut calon guru matematika (mahasiswa pendidikan matematika) untuk membekali dirinya ketika di bangku kuliah. Salah satu kompetensi yang diberikan yaitu kemampuan pedagogik. Dalam kompetensi pedagogik ini terdapat kegiatan evaluasi yang mutlak dilakukan seorang guru dalam setiap pembelajaran yang dilakukannya (Aslan-Tutak \& Adams, 2015; Ball, Thames \& Phelps, 2008; Goos, 2013; Mewborn, 2001). Namun hasil studi awal menunjukkan bahwa mahasiswa mengalami kesulitan ketika diminta 
melakukan proses evaluasi. Hal ini terlihat dari hasil tes tentang pengajuan soalmateri Geometri Lukis. Tes pengajuan soal yang diberikan sebanyak 2 soal. Soal pertama berkaitan dengan melukis garis dan sudut, sedangkan soal kedua berkaitan dengan melukis segitiga. Hasil tes pengajuan soal menunjukkan bahwa kemampuan mahasiswa masih rendah ketika membuat soal maupun dalam menyelesaikan soal yang telah dibuat. Sebanyak 25\% dari mahasiswa yang mampu dalam pengajuan soal Geometri Lukis (membuat soal dan menyelesaikannnya). Padahal kemampuan dalam mengajukan soal (pengajuan soal) merupakan hal penting bagi seorang guru dan merupakan aktivitas penting dalam matematika (Cankoy \& Darbaz, 2010; Turhan \& Guven, 2014). Dalam pembelajaran matematika sekolah, bidang Geometri selalu dipelajari dalam tiap jenjang pendidikan sekolah sehingga sebagai seorang calon guru harus menguasai keterampilan melukis dalam bidang Geometri (Geometri Lukis). Aktivitas kognitif dalam pengajuan soal ini meliputi pengajuan pre-solusi, pengajuan dalam solusi, pengajuan setelah solusi (Silver dan Cai, 1996:292).

Dalam pengajuan pre-solusi, soal yang dapat diajukan dalam Geometri Lukis misal, Terdapat garis $m$ dan garis $n$ seperti pada Gambar 1 .

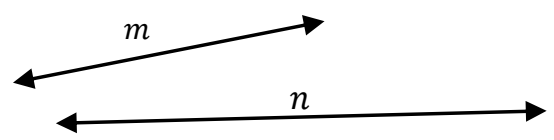

Gambar 1. Garis $m$ dan $n$

Buatlah satu soal yang berkaitan dengan melukis sudut dan selesaikan. Kemungkinan soal yang dibuat: "Diketahui garis $m$ dan $n$, dengan kaki sudut garis $m$ dan garis $n$, lukislah sudut $60^{\circ}$ ".

Soal yang dapat diajukan dalam pengajuan dalam solusi adalah sebagai berikut. Mahasiswa diberikan soal, "lukislah segitiga sama sisi DEF dengan keliling $(k)$ dalam $\mathrm{cm}, 5 \leq k \leq 9$ ". Mahasiswa diminta menyelesaikan soal tersebut. Dalam proses penyelesaian tersebut, mahasiswa diminta membuat soal baru yang serupa dengan soal yang diberikan. Soal baru yang dibuat dapat mengubah kondisi atau syarat dari soal yang telah diberikan. Misal,"lukis segitiga samakaki dengan keliling $(k)$ dalam cm, $5 \leq k \leq 9$ ". Sedangkan dalam pengajuan setelah solusi, soal yang dapat diajukan misal, diberikan soal, "lukislah sebuah segitiga sama sisi PQR dengan keliling $(k)$ dalam $\mathrm{cm}, 5 \leq k \leq 9$ ". Setelah dapat 
menyelesaikan soal tersebut, selanjutnya diminta membuat soal baru. Misal, "Perhatikan segitiga PQR di atas. Lukis segitiga sama sisi ABC dengan perbandingan sisi $\mathrm{AB}: \mathrm{PQ}=1: 2$ ".

Berdasarkan kondisi tersebut perlu dikembangkan sebuah modul Geometri Lukis yang mendukung kemampuan pengajuan soal. Modul yang dikembangkan ini dilengkapi dengan strategi untuk membantu mahasiswa dalam mengajukan soal serta latihan-latihan yang mendukung kemampuan pengajuan soal.

\section{METODE PENELITIAN}

Research and Development merupakan metode dalam penelitian ini. Model pengembangan yang digunakan yaitu 4-D yang meliputi define, design, develop, dan disseminate (Thiagarajan, 1974). Subyek penelitian adalah mahasiswa Pendidikan Matematika STKIP PGRI Sidoarjo tahun akademik 20182019. Uji coba terbatas dalam penilaian modul dilakukan kepada enam mahasiswa. Subyek penelitian ini terdiri dari mahasiswa dengan berkemampuan tinggi, sedang, dan rendah. Sedangkan uji coba lapangan melibatkan 60 mahahasiswa Pendidikan Matematika.

Instrumen dalam penelitian ini menggunakan lembar validasi, lembar angket, dan lembar tes. Angket digunakan untuk mengetahui kualitas modul yang dikembangkan melalui pertanyaan dan pernyataan, sedangkan tes digunakan untuk mengetahui kemampuan pengajuan soal matematika. Kualitas valid melalui analisis penilaian ahli, dengan rumus sebagai berikut:

$$
R T V=\frac{\sum_{i=1}^{n} A_{i}}{n}
$$

dengan $R T V=$ rata-rata total validitas perangkat pembelajaran; $A_{i}=$ rata-rata per aspek ke-I; $n=$ banyak aspek. Sedangkan kriteria kevalidan yang digunakan mengacu Khabibah(2006) diberikan pada Tabel 1.

Tabel 1. Kriteria Kevalidan Penilaian Ahli

\begin{tabular}{cc}
\hline$R T V$ & Kriteria \\
\hline $4 \leq R T V \leq 5$ & sangat valid \\
$3 \leq R T V<4$ & valid \\
$2 \leq R T V<3$ & kurang valid \\
$1 \leq R T V<2$ & tidak valid \\
\hline
\end{tabular}


Data hasil uji coba digunakan untuk mengetahui kelayakan modul yang dikembangkan.

\section{HASIL PENELITIAN DAN PEMBAHASAN}

Tahapan pengembangan modul ini yaitu pendefinisian (define), perancangan (design), pengembangan (develop), dan penyebaran (disseminate), diuraikan sebagai berikut.

Dalam tahap I yaitu Define dilakukan kegiatan front-end analysis,learner analysis, concept analysis, task analysis, specifying instructional objectives. Dalam front-end analysis dilakukan kajian terhadap kemampuan evaluasi mahasiswa pendidikan matematika dan kompetensi melukis dalam Geometri. Kemampuan evaluasi secara khusus dipelajari dalam mata kuliah Evaluasi Hasil Belajar. Berdasarkan wawancara dan hasil belajar menunjukkan bahwa kemampuan mengajukan soal mahasiswa masih rendah. Padahal kemampuan evaluasi merupakan salah satu kemampuan utama yang harus dimiliki oleh mahasiswa pendidikan matematika (Mahasiswa Calon Guru). Analisis tentang Geometri Lukis menunjukkan bahwa belum ada modul atau bahan ajar yang digunakan selama pembelajaran. Berdasarkan analisis di lapangan, dalam rangka menunjang kemampuan pengajuan soal pada materi Geometri Lukis, maka diperoleh beberapa hal yang harus ada dalam modul yang dikembangkan yaitu menyajikan latihan yang mendukung strategi dalam mengajukan soal, adanya soal-soal open ended yang mendukung kemampuan pengajuan soal.

Dalam kegiatan learner analysis dilakukan analisis terhadap kemampuan pengajuan soal mahasiswa dan latar belakang pengetahuan mahasiswa materi Geometri Lukis. Hal ini dilakukan melalui pemberian pretest pengajuan soal Geometri Lukis. Mahasiswa yang melakukan pretest sebanyak 32 mahasiswa. Hasil pretest menunjukkan bahwa sebanyak 25\% yang mampu mengajukan soal dan menyelesaikannya dengan benar. Aktivitas pengajuan soal yang dilakukan yaitu membuat soal dan menyelesaikannya.

Dalam kegiatan concept analysis dilakukan analisis terhadap materi Geometri Lukis. Kompetensi dalam Geometri Lukis yang diperlukan untuk membekali kompetensi kompetensi mahasiswa pendidikan matematika meliputi melukis sudut, melukis unsur-unsur segitiga, mengubah bentuk Geometri, melukis garis singgung, irisan bangun ruang, dan proyeksi. 
Dalam task analisis yaitu tugas atau solusi yang dirancang dalam menunjang permasalahan Geometri Lukis dan pengajuan soal. Modul yang dikembangkan didukung dengan strategi pengajuan soal yan ditunjukkan dalam bagan berikut.

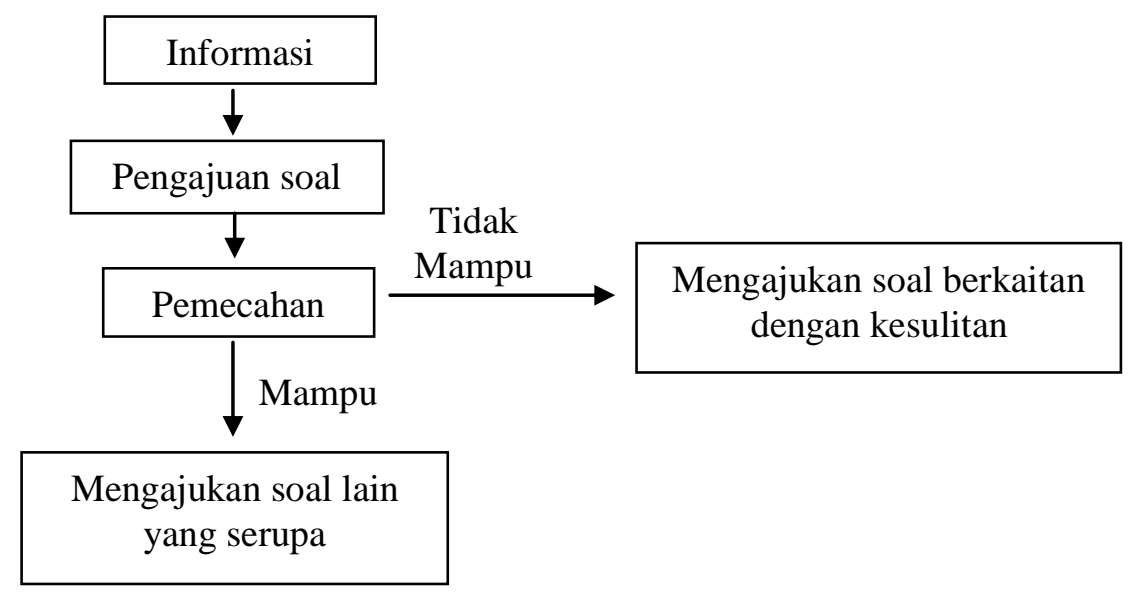

Gambar 1. Bagan Strategi Pengajuan Soal yang dikembangkan dalam Modul Geometri Lukis

Kegiatan specifying instructional objectives merupakan kegiatan perumusan analisis kompetensi (concept analysis) dan analisis tugas (task analisis) menjadi learning outcome pembelajaran Geometri Lukis. Beberapa indikator yang digunakan yaitu mahasiswa dapat menganalisis konsep-konsep Geometri Lukis dan menggunakan definisi dan langkah melukis dalam memecahkan masalah dan mengajukan masalah serta menyajikannya dalam bentuk sketsa sesuai konsep Geometri Lukis.

Pada tahap design meliputi constructing criterion-referenced test (penyusunan tes acuan), pemilihan media, pemilihan format, dan perancangan awal. Kegiatan constructing criterion-referenced test merupakan jembatan yang menghubungkan antara tahap define dan design. Kegiatan yng dilakukan meliputi penyusunan instrumen penelitian untuk menilai kelayakan modul. Kriteria valid modul diperoleh dari penilaian ahli. Kelayakan modul juga dilihat dari hasil respon pengguna (mahasiswa dan dosen) serta hasil tes.

Media yang digunakan untuk mendukung penggunaan modul meliputi visualisasi dua dimensi dan tiga dimensi langkah-langkah melukis geometri, jangka, dan penggaris. Beberapa pertimbangan media tersebut didasarkan pada, 1) modul yang disusun menuntut mahasiswa dapat melukis Geometri dua dimensi dan atau tiga dimensi, 2) media mudah diperoleh. 
Format modul disesuaikan dengan media yang digunakan dan strategi pengajuan soal. Strategi pengajuan soal dominan terlihat pada bagian latihan. Selanjutya dilakukan kegiatan perancangan awal. Dalam kegiatan ini, hasil semua analisis dari tahap define sampai kegiatan pemilihan format pada tahap design digunakan sebagai acuan dalam merancang modul. Dalam kegiatan ini diperoleh prototipe modul Geometri Lukis yang selanjutnya disebut draft-1. Kegiatan perancangan tahap awal ini dideskripsikan sebagai berikut. Struktur modul terdiri atas Judul, Capaian Pembelajaran, Latihan, Penilaian, Daftar Pustaka. Modul yang dikembangkan terdiri dari 6 pembahasan (bab).

Tahap ketiga yaitu develop, dalam tahap ini dilakukan validasi terhadap modul (draft-1). Hal ini digunakan untuk mengetahui kevalidan modul. Kegiatan validasi yang dilakukan meliputi penilaian uji kelayakan dan penilaian uji coba ahli. Tahap ini bertujuan untuk mengetahui saran secara tertulis maupun lisan terhadap kualitas draft-1. Hasil validasi ahli menunjukkan bahwa modul mempunyai kategori sangat valid dengan skor sebesar 4,64.

Modul yang telah divalidasi, selanjutnya dilakukan uji coba terbatas (uji keterbacaan). Uji coba ini dilakukan kepada 6 mahasiswa pendidikan matematika STKIP PGRI Sidoarjo. Uji coba ini dilakukan sebanyak 3 kali pertemuan. Analisis hasil uji coba terbatas digunakan untuk merevisi draft-1. Hasil perbaikan modul menjadi draft-2.

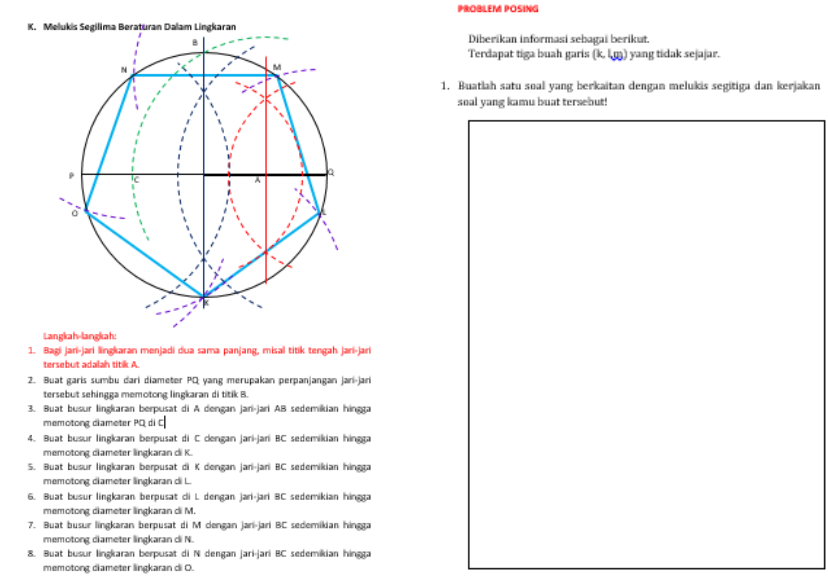

Gambar 2. Gambar Modul

Kegiatan berikutnya dalam tahap develop, yaitu uji coba lapangan. Dalam uji coba lapangan, subyek yang digunakan sebanyak 2 kelas mahasiswa pendidikan matematika STKIP PGRI Sidoarjo untuk megetahui kualitas draft-2. 
Respon dari mahasiswa dan dosen menentukan kualitas kelayakan modul (draft2). Angket yang digunakan terdapat 6 butir pernyataan favorable dan 6 pernyataan unfavorable dengan pilihan jawaban ya dan tidak. Kegiatan uji coba dan revisi dilakukan berulang sampai modul mempunyai kriteria kelayakan untuk digunakan.Berdasarkan uji coba diperoleh hasil penilaian modul melalui pengisisan angket sebesar 80,55. Hasil angket menunjukkan pengguna memberikan respon positif terhadap modul yang dikembangkan.

Berdasarkan hasil tes, tingkat pemodifikasian soal masih rendah. Sebagian besar mahasiswa membuat soal yang berkaitan dengan soal-soal yang diberikan selama pembelajaran atau yang terdapat dalam modul. Hal ini mengakibatkan rendahnya proses analisis yang dilakukan subyek penelitian ketika mengajukan soal (Nuriyatin \& Widadah, 2019). Namun dari hasil tes menunjukkan bahwa sebanyak $80 \%$ mahasiswa mampu membuat soal dan menyelesaikannya dengan benar.

\section{SIMPULAN}

Tahap define pada pengembangan modul ini diperoleh kriteria dalam modul yaitu menyajikan latihan pengajuan soal, soal-soal open ended yang mendukung kemampuan pengajuan soal. Materi modul meliputi melukis sudut, melukis unsur-unsur segitiga, mengubah bentuk Geometri, melukis garis singgung, irisan bangun ruang, dan proyeksi. Kriteria valid modul diperoleh dari penilaian ahli, sedangkan kelayakan modul diperoleh dari respon pengguna (mahasiswa dan dosen) serta hasil tes. Media yang digunakan meliputi visualisasi dua dan tiga dimensi dalam langkah-langkah melukis, jangka, dan penggaris. Format modul disesuaikan dengan media dan strategi pengajuan soal. Strategi pengajuan soal dominan terlihat pada bagian latihan. Pada tahap design diperoleh prototipe modul Geometri Lukis(draft-1). Modul yang dikembangkan terdiri dari 6 pembahasan (bab). Sedangkan tahap develop, diperoleh hasil validasi modul dengan kategori sangat valid dengan skor 4,64. Selanjutnya dilakukan uji coba lapangan terhadap modul yang sudah direvisi (draft-2) diperoleh hasil penilaian melalui pengisisan angket memberikan respon positif dengan skor 80,55. Sebanyak $80 \%$ mahasiswa mampu membuat soal dan menyelesaikannya dengan benar melalui tes. Berdasarkan hasil validasi dan uji coba menunjukkan bahwa 
modul yang dikembangkan mempunyai kategori sangat valid dan layak digunakan.

\section{DAFTAR PUSTAKA}

Aslan-Tutak, F., \& Adams, T. L. (2015). A Study of Geometry Content Knowledge of Elementary Preservice Teachers. International Electronic Journal of Elementary Education, 7(3), 301-318.

Ball, D. L., Thames, M. H., \& Phelps, G. (2008). Content Knowledge for Teaching: What Makes It Special? Journal of Teacher Education, 59(5), 389-407.

Cankoy, O. \& Darbaz, S. (2010). Effect of A Problem Posing Based Problem Solving Instruction on Understanding Problem. Hacettepe University Journal of Education, 38, 11-24.

Goos, M. (2013). Knowledge for Teaching Secondary School Mathematics: What Counts? International Journal of Mathematical Education in Science and Technology, 44(7), 972-983.

Khabibah, S. (2006). Pengembangan Model Pembelajaran Matematika dengan Soal Terbuka untuk Meningkatkan Kreativitas Siswa Sekolah Dasar. Surabaya: Disertasi. Tidak dipublikasikan.

Mewborn, D. (2001). Teachers Content Knowledge, Teacher Education, and Their Effects on The Preparation of Elementary Teachers in The United States. Mathematics Teacher Education and Development, 3, 28-36.

Nuriyatin, S. \& Widadah, S. (2019). Kemampuan Pengajuan Soal Geometri Lukis Mahasiswa Pendidikan Matematika. Prosiding Seminar Nasional Pendidikan Matematika 2019, p-ISSN 2528-4460, e-ISSN 2581-0634, 378-383.

Silver, E. A., \& Chai , J. (1996). An Analysis of Arithmetic Problem Posing by Middle School Students. Journal For Research In Mathematic Education, 27(5), 521-539.

Thiagarajan, S., Semmel, D. S., \& Semmel, M. I. (1974). Instructional Development for Trining Teachers of Exceptional Children. Minnesota: University of Minnesota.

Turhan, B. \& Guven, M. (2014). The Effect of Mathematics Instruction with Problem Posing Approach on Problem Solving Success, Problem Posing Ability and Views Towards Mathematics. Cukurova University Faculty of Education Journal, 43(2), 217-234. 